\title{
Equality and family responsibilities: a critical evaluation of New Zealand law
}

AMANDA REILLY*

\begin{abstract}
The causes of women's persistent inequality in the workplace are complex but work-family conflict and gendered patterns of care-giving undoubtedly play a role. This paper describes existing New Zealand law designed to prevent discrimination against those with family responsibilities and utilises regulatory scholarship to critically evaluate it. It concludes that stronger enforcement mechanisms and positive duties to promote workplace cultures where those with family responsibilities are not disadvantaged would be helpful additions to the existing legal framework.
\end{abstract}

\section{Introduction}

New Zealand women earn less than New Zealand men. Statistics New Zealand recently reported that the median weekly wage of women in full-time employment equates to $86 \%$ of the median male wage. ${ }^{1}$ Measured by average hourly earnings, the gender pay gap has persisted at $12 \%$ for the last 10 years. ${ }^{2}$ There are a number of reasons for this pay gap which include systemic under compensation of female dominated occupations and overt sex discrimination. This paper concentrates on one aspect of the underlying causes of the pay gap, i.e. work-family conflict and gendered patterns of care giving, and it evaluates New Zealand's legal responses thereto.

The paper is structured as follows: In the first part, the relationship between women's disadvantage in the workplace and the ideal worker norm is discussed. In the second part, some concepts drawn from regulatory scholarship are summarised with a few examples providing criteria against which to evaluate New Zealand law. In the third part, New Zealand law is analysed and found wanting.

\section{How do gendered care work norms contribute to women's disadvantage?}

Williams argues that women will remain disadvantaged and marginalised in workplaces for as long as the norm of the ideal worker is someone unconstrained by care-work responsibilities, i.e. somebody who is able to work 40 hours or more a week, all year round with no career breaks. ${ }^{3}$ As long as this norm prevails, anyone who deviates from it will find themselves disadvantaged.

The ideal worker norm is problematic because it does not sufficiently take account of care-work. Historically, this work was largely carried out, unpaid, in the private sphere by women. However, as increasing numbers of women have moved into paid work, the need for care-work has not diminished. Care-work is intrinsic to the continuation and sustenance of human life. The labour intensive nurture of babies and children is the most obvious manifestation of this but it is not the only one. Childless, single people have care-giving calls on their time too, more particularly if they have elderly relatives for whom they are responsible. Moreover, the current understanding of work as work-for-pay or as

\footnotetext{
* Lecturer in Law, School of Accounting and Commercial Law, Victoria University of Wellington

${ }^{1}$ Statistics New Zealand "New Zealand Income Survey: June 2010 Quarter” (2010) <www.stats.govt.nz>.

${ }^{2}$ Human Rights Commission "Tracking Equality at Work" (2011) at 26 <www.hrc.org.nz>.

${ }^{3}$ Joan Williams Unbending gender: Why Family and Work Conflict and What to Do About it (Oxford University Press, Oxford, 2000).
} 
employment rather than as the whole sum of the labour it takes to keep a household functioning is highly artificial. Paid work is, in fact, parasitic on care-work. Most obviously, if one is to be productive in the workforce, washing will have to be done, meals prepared and eaten, and health (both emotional and physical) maintained.

Mere formal equality for women to compete as an ideal worker can never promote substantive equality for women because care-work is simply not going to disappear. Somebody will have to do it and that person is most often a woman. ${ }^{4}$ The fact that women carry this burden is a major contributor to their disadvantaged and marginalised status in the workplace. While individual women's decisions to de-prioritise workplace participation in order to accommodate care-work are often framed as a consequence of individual choice, gender equality is not an individual issue. It is a social and structural issue linked to women's disproportionate responsibility for family care-work.

The current distribution of care-work and ideal worker norm also impacts on men. As noted by Williams: ${ }^{5}$

Hegemonic masculinity [has come to be] defined in terms of work roles...masculine dignity is linked with success at work...Gender pressures on men are a key reason for the "stalled revolution" in work and family life... a key to jump starting the revolution is to change gender pressures on men by changing the way we define the ideal worker.

The idealisation of the unencumbered worker contributes to pressure on men to fulfil the primary breadwinner role. Overseas studies suggest that men who compromise their paid work participation to take on a greater share of family responsibility care work are more disadvantaged than their female equivalents as they are punished for deviating from established gender roles. ${ }^{6}$ As long are men are effectively discouraged from taking on a greater share of care-work, women will continue to carry this load and accordingly be disadvantaged in the workplace.

The heart of the problem is the fact that workplaces are structured around an ideal worker who is not a care-worker. ${ }^{7}$ This, in conjunction with gender role expectations, means that all too frequently men and women end up respectively in ideal worker and marginalised care-worker roles. ${ }^{8}$ As a matter of fairness this needs to change; workplaces should be structured in ways that allow individuals to meet the legitimate needs of those dependent on them as well as their own needs. In order to achieve this, the norm of the ideal worker, as one unencumbered with responsibilities, must be replaced by the norm of the worker with care-work responsibilities.

While shifting entrenched norms is difficult and complex, Smith suggests that "around the world law is being used to provide worker rights designed to challenge the ideal worker norm and facilitate the integration of workers who have family responsibilities." "The question posed here is how well New Zealand law is adapted to meeting this challenge? In the next section, some concepts drawn from regulatory theory on what makes law effective are summarised with a view to providing some criteria against which New Zealand law can be analysed.

\footnotetext{
${ }^{4}$ Around two-thirds of unpaid work in English-speaking countries is performed by women, see Human Rights Commission, above n 2, at 10 .

5 Joan Williams "From Difference to Dominance to Domesticity: Care as Work, Gender as Tradition" (2001) 76 Chicago

Kent Law Review 1441 at 1444.

${ }^{6}$ Belinda Smith "Not the Baby and the Bathwater: Regulatory Reform for Equality Laws to Address Work-Family

Conflict" (2006) 28 Sydney Law Review 689.

${ }^{7}$ Williams, above n 5, at 1474 .

${ }^{8}$ Ibid, at 1471 .

${ }^{9}$ Smith, above n 6, at 691.
} 


\section{What makes law effective?}

The mere fact that a law prohibiting discrimination exists is not enough to ensure that people with family responsibilities are not discriminated against or disadvantaged as a consequence of deviating from the ideal worker norm. As Murray states "law does not work by automatic fiat, but requires some kind of internalisation to ensure its effectiveness." to make law effective and to ensure that the law's goals are internalised by individuals and organisations. ${ }^{11}$ Ayres and Braithewaite most influentially developed the idea of an enforcement pyramid that reflects the range of regulatory strategies. ${ }^{12}$

At the bottom of the pyramid is "soft touch" mechanisms designed to educate and persuade organisations to adopt desired behaviours. In the case of work family issues, this might include making both the moral and business case for equality for people with care-work responsibilities. At the next level, reporting requirements on practices and initiatives encourage both organisational reflection and accountability external stake holders. Reporting can also encourage comparisons and learning between organisations.

Effectively, the law and state institutions at the bottom of the pyramid help organisations to selfregulate. However, the soft persuasive tools at the bottom of the pyramid are most effective when, at the top of the pyramid, there are also punitive sanctions. The regulator must have access to "a big stick" and the ability to punish those on whom the softer approaches have proven ineffective. These might include penalties for non-compliance or, where appropriate, corrective orders which require an organisation to self review and develop and report upon a compliance programme.

Another relevant development in regulatory theory that is reflected in the legislative provisions in other jurisdictions is a movement towards imposing positive duties on employers and institutions to proactively promote equality. ${ }^{13}$ This trend is a response to weaknesses identified in the individual complaints led model based around negative rights such as the right not to be discriminated against. Some of these weaknesses, as summarised by Fredman, are as follows. ${ }^{14}$ Individual actions alleging discrimination are not suited to achieving significant or systematic progress towards gender equality goals. In order for an individual complainant to succeed, they must be able to prove a perpetrator, however, inequality is largely institutional and not necessarily the fault of any particular person. Even if claim is successful and while this may provide compensation of individuals, it will not trigger any ongoing obligations to correct the institutional structure. Furthermore, reliance on individual complainants to bring an action puts excessive strain on the victim as the process can be lengthy, expensive and uncertain. Courts can only intervene on random and ad hoc basis as many individuals, especially if un-unionised, will be unable to pursue claims.

\section{Critical Evaluation of New Zealand Law}

New Zealand has various strategies from the bottom of the regulatory pyramid (i.e. soft tools of education and persuasion) in place concerning the need for gender equality and family-friendly workplace practices in place. These include the Department of Labour's Work-Life Balance project which

\footnotetext{
${ }^{10}$ Jill Murray "Corporate Social Responsibility: An Overview of Principles and Practices: Working Paper No 34” (2004) International Labour Organisation at $5<w w w . i l o . o r g\rangle$.

${ }^{11}$ This summary draws heavily on Smith's discussion (Smith, above, n 6, at 705-707).

${ }^{12}$ I Ayres and J Braithewaite Responsive Regulation: Transcending the Deregulation Debate (Oxford University Press, Oxford, 1992).

${ }^{13}$ For discussion, see Human Rights Commission, above n 2, at 27.

${ }^{14}$ Sandra Fredman "Changing the Norm: Positive Duties in Equal Treatment Legislation" (2005) 12 Maastricht Journal of European and Comparative Law 369.
} 
makes a number of Best Practice Resources available on its website. ${ }^{15}$ The Human Rights Commission, in partnership with the EEO Trust, also works to promote equal employment opportunities by disseminating information and resources to interested parties. ${ }^{16}$ Such initiatives may well have achieved some normative change in individual work-places and are not to be disparaged.

However, as discussed earlier, according to Ayres and Braithwaite, effective regulation requires a regulator with access to a full pyramid of regulatory responses with the possibility of punitive sanctions for those who fail to respond to soft law initiatives. Here, New Zealand's legal framework falls short. Beyond provision of information, these bodies have limited capacity to motivate or prompt commitment from employers. No regulatory agency in New Zealand has access to punitive sanctions with which to punish employers who discriminate against workers with family responsibilities.

Individuals who have been discriminated against because they are responsible for children or other dependents may have a remedy against their employer under the Human Rights Act. ${ }^{17}$ This is so whether the discrimination is direct or indirect. Direct discrimination would include being denied a job, equal pay or opportunities for progression on the grounds of prejudices or stereotypes. A failure to reasonably accommodate a person's family and caring responsibilities by agreeing to flexible hours may amount to indirect discrimination. ${ }^{18}$ The Employment Relations Act also allows employees to bring a personal grievance against an employer where they have been discriminated against on family status grounds. ${ }^{19}$

However, the fact that complaints have to be initiated and pursued by the individual victims of discrimination limits the value of these provisions in terms of their ability to effect systemic change as discussed above. The value of these provisions is also limited by the fact that complaints against employers under both the Human Rights Act and the Employment Relations Act are directed at first instance to mediation, the proceedings of which are not widely reported on or freely available in the public domain.

The Human Rights Commission reports that in the period 2005-2010 6.1\% of the discrimination complaints they received concerned family responsibilities discrimination. ${ }^{20}$ Clearly, the law is being utilised to a limited extent by individuals, but the paucity of recent reported cases on family responsibilities discrimination suggests that these complaints are largely being settled at mediation. ${ }^{21}$ While mediation may have some advantages in terms of keeping the costs of litigation down, it also has disadvantages. Employers who discriminate against workers with family responsibilities run little risk of being publically identified. Fiss argues that the primary purpose of adjudication is the reiteration of societal norms by authoritative decision makers ${ }^{22}$ if there were widely publicised court decisions on family responsibilities discrimination, this would both punish individual employers for discriminatory practices and raise awareness of the need to avoid such practices among other employers. Such decisions would also feed into a broader societal dialogue and inform various civil

\footnotetext{
${ }^{15}$ Department of Labour "Work-life balance in New Zealand" <www.dol.govt.nz>.

${ }^{16}$ National Equal Opportunities Network “About Us" (2012) <www.neon.org.nz>.

${ }^{17}$ Proceedings Commissioner v Howell [1993] 2 ERNZ 130, (1993) 4 NZELC 98,210 establishes that discriminating against a woman with children because of her childcare responsibilities amounts to discrimination on the grounds of family status.

${ }^{18}$ Drfyhout v New Zealand Guardian Trust Ltd (1997) 3 HRNZ 572

${ }^{19}$ Employment Relations Act 200, s 103(1)(c). Section 105 (1)(1) mirrors the prohibited grounds of discrimination set out in section 21(1) of the Human Rights Act 1993.

${ }^{20}$ Human Rights Commission, above n 2, at 20.

${ }^{21}$ The only recent reported case is Claymore Management Ltd $v$ Anderson [2003] 2 NZLR 537(HC) which concerned the resignation of a part time-legal employee who had family care responsibilities. The appellant employer successfully argued the resignation was not caused by direct or indirection family status discrimination. However, the court commented that the case was unsuitable to set precedent as the Tribunal had not discussed family status.

${ }^{22}$ Owen Fiss “Against Settlement” (1984) 93 Yale Law Journal 1073.
} 
groups who would in turn be better placed to be involved in the monitoring and enforcement of appropriate standards

There are other legislative provisions which provide individual workers with rights intended to enhance their ability to participate in the work place. ${ }^{23}$ Part $6 \mathrm{AA}$ of the Employment Relations Act provides certain employees with the care of any person a right to request a variation of their working hours. It also set out a process employers must follow in terms of considering the request. If following this an employee is unhappy he or she must first approach a Labour Inspector from the Department of Labour before it is possible to proceed to mediation. After this, there is a possibility of an application to the Employment Relations Authority; however, there is no possibility of appeal to the Employment Court. The maximum penalty the Authority can order is $\$ 2000$, which is payable to the employee concerned.

This provision may be helpful to some employees. However, the fact that any complaint must be individually driven by an individual (who is almost certainly time-pressed) and the lack of any significant penalty or possibility of name and shaming of employers who fail to follow correct process must limit its efficacy. The extent to which carers are aware of this right is also questionable. A recent survey found that most PSA women (59\%) were not familiar with the legislation. ${ }^{24}$

New Zealand does not impose any positive duty on employers to actively implement policies which assist workers with family responsibilities. The exception to this is the good employer obligation in the Crown Entities Act. ${ }^{25}$ This requires each Crown Entity to operate a personnel policy that complies with the principle of being a good employer which takes into account the employment requirements of women. The Human Rights Commission has identified seven key elements of the personnel policies of good employers; element four is as follows:

\section{Flexibility and Work Design}

Workplace design and organisation takes account of the need to assist employees to balance work with the rest of their lives and ensures managers relate to employees in a respectful and flexible way, considering the employment requirements of all groups including parents and other carers.

In addition to operating a personnel policy which complies with the good employer obligation, Crown entities have annual reporting requirements. The EEO Commissioner assesses these annual reports looking for references to being a good employer, EEO and the seven key good employer elements.

The combination of a positive duty to be a good employer and the requirement to report on progress go some way towards encouraging Crown entities to self regulate to create family-friendly working environments where those who have family responsibilities are not discriminated against. However, this initiative does not go far enough. Neither the good employer duty nor the associated reporting requirements apply to the private sector which employs around $80 \%$ of the workforce. The Human Rights Commission has recommended that the Employment Relations Act (2000) be amended to include a positive duty to be a good employer in both the public and private sectors and this would be a significant improvement on the existing state of affairs. ${ }^{26}$

\footnotetext{
${ }^{23}$ See for example, the Parental Leave and Employment Act 1987. This is not discussed here as this paper is concerned with the accommodations needed for care givers in general across a life cycle rather than the specific needs arising out of pregnancy, child birth and breast feeding.

${ }^{24}$ Sarah Proctor-Thomson, Noelle Donnelly, Geoff Plimmer Constructing Workplace Democracy: Women's Voice in New Zealand Public Services (Industrial Relations Research Centre and Management School Victoria University of Wellington April 2011) at 21-22.

${ }^{25}$ Crown entities with employees are required to be 'good employers.' See Crown Entities Act 2004, ss 118 and 151 (1) (g).

${ }^{26}$ Human Rights Commission, above n 2, at 4.
} 
However, more is needed. McCrudden identifies it as a pre-condition of effective reflexive regulation that there be some mechanism whereby firm and public bodies are required to engage with other stakeholders. ${ }^{27} \mathrm{He}$ comments on the experience of Northern Ireland where, under the equality duty public, authorities are required to engage with civil society in detailed ways. He concludes that forced engagement with a "truculent and well-informed civil society" is fundamental to the operation of reflexive regulation. This suggests that reporting requirements should be more extensive than they currently are so that a wide range of interested parties can play a role in rewarding good employers and pressurising bad employers.

\section{Conclusion}

A common thread runs through New Zealand law with regard to the prevention of family responsibilities discrimination and integrating care-givers into the workforce: there is no big stick. Employers who do not respond to education and persuasion need not fear punishment or public shaming. While individual workers have rights, it is up to these individuals to enforce these rights, which may come at a high personal cost and which, at best, will provide individual compensation rather than systemic change. The lack of effective enforcement mechanisms weakens the impact of soft law educative mechanisms as it reduces incentives for employers to change their behaviours. The lack of publicised cases and of strong visible enforcement mechanisms also detrimentally impact on consciousness raising in wider civil society which is, thus, stymied in terms of being able to put pressure on organisations to adopt policies which give those with family responsibilities a fair deal. The vast majority of employers are not subject to positive duty to create non discriminatory, familyfriendly work places. Law change is necessary if the ideal worker norm is to be replaced in New Zealand workplaces. Until such time as this happens, New Zealand women are likely to remain disadvantaged in the workplace and will probably continue to earn less than men.

\footnotetext{
${ }^{27}$ Christopher Mc Crudden "Equality Legislation and Reflexive Regulation: a Response to the Discrimination Law Review's Consultative Paper" (2007) 36 Industrial Law Journal 255 at 265.
} 
Reproduced with permission of the copyright owner. Further reproduction prohibited without permission. 